\title{
PALABRAS CERCANAS
}

No porque vienen de la boca con vida del padre. No porque pueden morderse y saben dulces. No porque suenan cerca de tu oído. Palabras cercanas. No buscan lo que no has visto, no corren hacia encuentros que no has tenido.

Se dejan sobar como un perro manso, se alegran si las tocas, te agradecen el contacto físico. Se pasean desnudas dentro de tu casa. Se esconden en tus sábanas. Olfatean tu ropa interior. Tu deseo les parece lo más natural. Leen los muros de tu casa sin alarmarse. No desean sorprenderte.

Se mueven entre el aroma a vainilla y los vapores tibios cuando preparas un helado artesanal. Se elevan cuando huele a tierra mojada. Buscan esta presencia y no se precipitan. No forman parte de nada más. Solo de este momento. No te engañan, soportan tus engaños.

Toleran cualquier página en los libros. Pueden darte la espalda si les da la gana, no andan con buenos modales, no se preocupan por su olor, pero por lo general huelen bien. Caminaron alrededor del cuerpo de tu

110 abuela pero no convirtieron su muerte en algo trágico. Abrieron los perfumeros como si la vida siguiera por ahí. Se sentaron en la alfombra junto a ti, y vieron sus pies. Le dieron la última caricia. Se meten bajo el suéter negro de tu padre y escuchan su corazón.

Miran tus pesadillas y se ríen. Cortan los hilos que sobran en los tejidos de tu casa. Hacendosas, limpian tus libros, leen sus lomos y mansamente ofrecen el suyo. Tus manos no enfrían su piel. Son dóciles y nunca golpean la puerta. Encuentran siempre la forma de pasar. Se pegan como el buen polvo a los marcos y no hacen mucho ruido.

Apagan la luz cuando tienes sueño. Dejan marcas sobre la mesa si aprietas de más el cuchillo. Prefieren verbos como embarrar, embadurnar. Sugiero que desconfíes de su comodidad, no sea que un día no te dejen entrar a casa.

(Del libro Parcela blanca) 